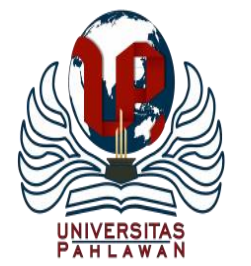

Edukatif : Jurnal Ilmu Pendidikan Volume 2 Nomor 2 Tahun 2020 Halm 194-

EDUKATIF: JURNAL ILMU PENDIDIKAN

Research \& Learning in Education

https://edukatif.org/index.php/edukatif/index

\title{
Peran dan Tugas Kepemimpinan Kepala Sekolah di Sekolah Dasar
}

\author{
Inge Kadarsih ${ }^{1}$, Sufyarma Marsidin ${ }^{2}$, Ahmad Sabandi ${ }^{3}$, Eka Asih Febriani ${ }^{4}$ \\ Universitas Negeri Padang, Sumatera Barat, Indonesia ${ }^{1-4}$ \\ E-mail : ingekadarsih27@gmail.com ${ }^{1}$ sufyarma@gmail.com ${ }^{2}$ sabandi@fip.unp.ac.id ${ }^{3}$ \\ ekaasihsyafitri@fis.unp.ac.id ${ }^{4}$
}

\begin{abstract}
Abstrak
Tujuan pembahasan ini adalah untuk mengetahui serta menganalisis peran dan tugas utama kepemimpinan kepala sekolah SD. Metode kepustakaan (library research) digunakan sebagai metodologi penelitian dalam penelitian ini. Teknik pengumpulan data dalam pembahasan ini yaitu dengan mengkaji atau mengeksplorasi beberapa buku, jurnal, serta dokumen lain yang dianggap relevan. Penelitian ini membahas yang penting dalam pendidikan yaitu bagaimana bentuk kepemimpinan, dan tugas utama kepala sekolah di SD. Kepemimpinan kepala sekolah merupakan penentu keberhasilan terwujudnya tujuan pendidikan di sekolah yang telah diuraikan dalam visi dan misi sekolah. Tugas utama kepala sekolah adalah sebagai manajerial, supervisor, dan sebagai pemimpin kewirausahaan. Kepala sekolah sebagai guru yang diberi tugas dalam mengelola dan memimpin sekolah harus tahu dan paham serta dapat mengaplikasikan apa yang menjadi tugas utama seorang kepala sekolah dalam bentuk tindakan nyata dalam memimpin dan memajukan sekolah dan pendidikan di Indonesia ini seperti yang telah tertuang pada Permendikbud No. 6 Tahun 2018. Agar menghasilkan output yakni peserta didik yang beriman dan bertaqwa kepada Allah Yang Maha Kuasa, berakhlak mulia, dan cerdas serta tangguh dan mampu menyelesaikan semua problematika dalam kehidupannya.
\end{abstract}

Kata kunci: kepala sekolah, kepemimpinan, tugas utama kepala sekolah

\section{Abstract}

The purpose of this discussion is to find out and analyze the primary roles and tasks of elementary school principal leadership. The library research method is used as a research methodology in this study. Data collection techniques in this discussion is by reviewing or exploring several books, journals, and other documents that are considered relevant. This research discusses what is important in education, what is the form of leadership, and the main task of principals in elementary schools. The principal's leadership is a determinant of the success of the school's educational goals that have been described in the vision and mission of the school. The principal job of the principal is as managerial, supervisor, and as an entrepreneurial leader. Principals as teachers who are given the task of managing and leading schools must know and understand and be able to apply what is the main task of a school principal in the form of concrete actions in leading and advancing school and education in Indonesia.. In order to produce outputs that are students who believe and are devoted to Allah Almighty, have good morality, and are intelligent and tough and are able to solve all the problems in their lives.

Keywords: principal, leadership, principal principal duties

Copyright (c) 2020 Inge Kadarsih, Sufyarma Marsidin, Ahmad Sabandi, Eka Asih Febriani

$\triangle$ Corresponding author :

Address : Universitas Negeri Padang

Email : ingekadarsih27@gmail.com

ISSN 2656-8071 (Media Cetak)

DOI: https://doi.org/10.31004/edukatif.v2i2.138

ISSN 2656-8063 (Media Online)

Edukatif : Jurnal Ilmu Pendidikan Vol 2 No 2 Tahun 2020 p-ISSN 2656-8063 e-ISSN 2656-8071 
195 Peran dan Tugas Kepemimpinan Kepala Sekolah di Sekolah Dasar - Inge Kadarsih, Sufyarma Marsidin, Ahmad Sabandi, Eka Asih Febriani

DOI: https://doi.org/10.31004/edukatif.v2i2.138

\section{PENDAHULUAN}

Pendidikan merupakan usaha sadar dan terencana untuk membentuk dan mengembangkan segala bakat, potensi, minat, dan seluruh kemampuan anak agar menjadi manusia yang cerdas spritual, emosional, dan intelektual. Sehingga terbentuklah kepribadian anak atau generasi bangsa yang beriman dan bertaqwa kepada Allah Yang Maha Kuasa, berakhlak mulia, terampil, cerdas, bertanggung jawab, sehat, kuat, dan mandiri.

Untuk mewujudkan generasi (output) sekolah yang berkarakter dan berkualitas, salah satunya ditentukan oleh tugas atau peran serta fungsi kepala sekolah. Kepala sekolah merupakan orang kunci (key personal) menata masa depan keberhasilan pendidikan di setiap satuan sekolah (Wahyosumidjo. 2018:82). Sesuai dengan tugas dan fungsinya, kepala sekolah tidak saja diharapkan menjadi pemimpin, fasilitator, ataupun dinamisator saja. Namun lebih dari itu diharapkan bisa menjadi acuan, teladan, tolak ukur, bahkan sebagai sumber referensi bagi komunitas sekolah tersebut. Kemana sekolah ini akan dibawa? Tentu untuk mengantarkan pada tujuan yang tepat sasaran, bak anak panah yang berhasil melesat tepat mengenai target. Maka kepala sekolah di sini merupakan si pemanah.

Oleh sebab itu kepala sekolah harus memiliki keahlian/skill, kompetensi dan terus melatih diri, memiliki, dan memahami akan tugas pokoknya sebagai kepala sekolah, dan juga memahami kompetensi-kompetensi yang telah ditetapkan yang dapat teraktualisasi dari wujud sikap, perilaku atau perbuatan, keputusan, dan kebijakan-kebijakan yang diambil oleh kepala sekolah demi keluaran (output) sekolah yang berkarakter dan bermutu yang nantinya ditangan merekalah masa depan bangsa ini akan diserahkan.

Kepala sekolah adalah guru yang dilantik menjalankan pimpinan sekolah. Atau ditugaskan menjadi pemimpin sekolah untuk memajukan dan meroketkan pencapaian tujuan sekolah. Kepala sekolah menduduki tugas penting dalam mengarahkan semua personil sekolah yang ada, agar dapat bekerja sama dalam mencapai tujuan sekolah. Perilaku kepemimpinan kepala sekolah yang efektif mempengaruhi kinerja guru. Sebagai pemimpin kepala sekolah mencerminkan tanggung jawabnya dengan menggerakkan sumber daya yang ada di sekolah.

Fungsi kepemimpinan kepala sekolah dalam menjalankan tiga tugas pokoknya tersebut sangat penting, sebab di samping sebagai penggerak juga sebagai pengontrol segala aktivitas pendidik, tenaga kependidikan, penjaga sekolah, peserta didik dan sekaligus pemerhati dan pemberi solusi masalah-masalah yang muncul di sekitar lingkungan sekolah (Wahyosumidjo, 2010).

Sebagai pemimpin sekolah dalam menjalankan tupoksi kepala sekolah haruslah memperhatikan dan betul-betul melaksanakan tupoksi tersebut, karena jika hanya fokus pada tugas dalam pengadaan sarana dan prasarana saja akan membuat guru lalai dan lengah sebagai pendidik dan pembentuk nilai moral atau karakter pada anak didik. Tentu akan membentuk dan menumbuhkan potensi negatif guru dalam menjalankan tanggung jawabnya di sekolah dan tentunya akan berimplikasi pada kualitas keluaran 
196 Peran dan Tugas Kepemimpinan Kepala Sekolah di Sekolah Dasar - Inge Kadarsih, Sufyarma Marsidin, Ahmad Sabandi, Eka Asih Febriani

DOI: https://doi.org/10.31004/edukatif.v2i2.138

(output) sekolah yang buruk atau tidak berkarakter, tidak berkualitas, dan tidak bermental tangguh.

Oleh sebab itu sebagai calon pendidik dan calon pendidik yang diamanahkan tugas kepala sekolah serta pakar pendidikan sekolah dasar merupakan tanggung jawab bersama bagi kita untuk mengkaji lebih dalam isi dari Permendikbud No. 6 Tahun 2018 mengenai tanggung jawab mulia sebagai manajerial, tugas supervisor, dan tugas pemimpin kewirausahaan. Kita tentu sangat mengharapkan agar tupoksi kepala sekolah tidak semata hanya dibaca dan dibiarkan keluar melalui salah satu telinga setelah telinga satunya lagi menerima dengan membaca tupoksi kepala sekolah tersebut. Namun besar harapan kita pembedahan materi ini akan lebih membuat kita tidak sebatas baca, dan tahu saja. Akan tetapi kita bisa sebagai pelaku yang dapat menerapkannya dengan sungguh-sungguh dan totalitas dan tentu disesuaikan dengan keadaan dan kondisi akan peran kita sekarang ini. Karena jika kita tidak sebagai pelaku pelaksana tupoksi kepala sekolah namun kita juga bisa menjadi tempat bertanya atau sharing yang dapat memberikan pengaruh kepada pendidik atau calon pendidik.

\section{METODE PENELITIAN}

Metode yang digunakan dalam penelitian adalah metode studi kepustakaan (library research). Studi pustaka atau kepustakaan merupakan kegiatan pengumpulan data dari berbagai sumber bacaan (Harahap, 2014).

Data yang digunakan dalam menyelesaikan penelitian ini berasal dari sumber berupa buku, jurnal serta artikel yang sesuai dengan penelitian ini.

\section{HASIL DAN PEMBAHASAN PENELITIAN}

\section{Esensi Kepala Sekolah}

Dalam mewujudkan tujuan pendidikan nasional yakni membentuk generasi penerus bangsa yang akan melanjutkan pembangunan negeri Indonesia ini dibutuhkan suatu lembaga pendidikan formal yakninya sekolah. Dalam hal ini yang dimaksud adalah sekolah dasar (SD). Dalam Undang-undang tentang sistem pendidikan nasional sudah diatur bagaimana penyelenggaraan dan pengelolaan serta pelaksanaan maupun evaluasi sekolah. Semuanya sudah diatur sedemikian rupa. Begitupun sekolah yang harus mempunyai pimpinan di sekolah yang masih dari kalangan guru.

Pemerintah telah mengeluarkan Peraturan Menteri Pendidikan dan Kebudayaan yang terbaru baru-baru ini tentang jabatan kepala sekolah yang masih berasal dari guru, namun berbeda makna dari peraturan yang sebelumnya. Di Permendikbud No.6 Tahun 2018 ini disebutkan esensi kepala sekolah adalah guru yang diamanahkan tugas dalam melaksanakan perannya membina atau memimpin sekolah. Tentu dalam hal ini kepala sekolah yang berasal dari guru sudah memiliki peran yang lebih luas dari sebelumnya, yang paling signifikan dari sebelumnya adalah kepala sekolah tidak lagi dibebankan dalam mengajar di kelas. Dengan arti kata jam kepala sekolah yang biasanya ada enam jam sekrang sudah tidak ada lagi, karena kepala sudah difokuskan kepada tugas 
197 Peran dan Tugas Kepemimpinan Kepala Sekolah di Sekolah Dasar - Inge Kadarsih, Sufyarma Marsidin, Ahmad Sabandi, Eka Asih Febriani

DOI: https://doi.org/10.31004/edukatif.v2i2.138

dan pokonya sebagai kepala sekolah, yang nantinya di halaman selanjutnya ini akan dibahas lebih lanjut tentang peran utama kepala sekolah.

Kepala sekolah merupakan seorang leadership yang akan memberikan sejumlah tugas dan peran kepada koleganya untuk mencapai tujuan dan sasaran yang telah disepakati di mana di dalamnya terjadi interaksi proses pembelajaran di dalam kelas ataupun di luar kelas dan memperhatikan seluruh komponen yang terdapat di sekolah untuk mencapai tujuan dan sasaran yang disepakati tersebut yang tidak lain dan tidak bukan adalah visi dan misi sekolah (Wahyosumidyo, 2002:83).

Sehingga dapat disimpulkan kepala sekolah bukan sekedar guru yang diberi tugas dalam menjalankan atau mengelola sekolah, namun juga bagaimana semua anggota atau individu yang ada di sekolah memiliki kebertanggungjawaban dalam menjalankan perannya masing-masing dengan totalitas yang akan membawa pada tujuan atau sasaran yang akan dicapai yakninya membentuk generasi penerus atau dalam hal ini anak didik menjadi generasi yang cerdas spiritual, emosional, dan intelektual, yang tidak lain dan tidak bukan adalah pencapaian tujuan pendidikan nasional pada intinya.

\section{Kepemimpinan Kepala Sekolah}

Pendidikan merupakan dunia yang akan merubah manusia yang dari tidak tahu menjadi tahu, dari tidak pandai menjadi pandai, dari yang tidak baik menjadi baik, dan dari yang tidak berakhlah menjadi berakhlak mulia, yang dikenal dengan memanusiakan manusia menjadi manusia seutuhnya baik berkembang fisiknya maupun psikisnya, baik tumbuh dan berkembang ruhiya maupun jasmaniyah.

Seperti yang dijelaskan di atas bahwa sekolah adalah salah satu tempat mengembangkan manusia menjadi manusia seutuhnya, maka sekolah perlu pemimpin. Pemimpin di sini kepala sekolah yang setiap kepala sekolah mempunyai gaya kepemimpinan masing-masing namun pada dasarnya memiliki tujuan dan sasaran yang sama untuk mewujudkan tujuan pendidikan nasional seperti yang telah dijelaskan di atas.

Gaya kepemimpinan kepala sekolah ini adalah bagaimana sikap, gesture atau bahasa yang digunakana untuk menggerakkan, memotivasi, mengelola, merancang program-program dan melaksanakan program-program yang telah disusun bersama kolega guru dan semua personil yang ada dalam mencapai tujuan sekolah yaitu visi dan misi sekolah.

Keberhasilan semua kolega guru dan semua tenaga kependidikan merupakan ciri keberhasilan kepala sekolah memimpin sekolah. Tentu gaya kepemimpinan yang digunakan mampu memberi andil kepada semua personel yang ada untuk bekerja totalitas menjalankan masing-masing perannya. Tidak hanya itu kepemimpinan kepala sekolah juga mempengaruhi anak didik lebih bersemangat dalam belajar dan mengembangkan bakat, minat dan potensinya secara maksimal. Dalam keberhasilan ini baik dari guru maupun anak didik di sekolah tidak terlepas dari kepemimpinan kepala sekolah yang telah sukses dalam mempengaruhi semua orang yang ada di sekolah, baik dengan memotivasi, memfasilitasi, 
198 Peran dan Tugas Kepemimpinan Kepala Sekolah di Sekolah Dasar - Inge Kadarsih, Sufyarma Marsidin, Ahmad Sabandi, Eka Asih Febriani

DOI: https://doi.org/10.31004/edukatif.v2i2.138

memberi contoh serta merancang dan menyusun program-program yang menunjang tercapainya tujuan pendidikan sekolah (Ekosiswoyo, 2016).

Oleh sebab itu semua kepala sekolah yang ada di seluruh Indonesia haruslah menjalankan tugas, peran dan fungsinya sebagai kepala sekolah. Karena kepala sekolah merupakan tiang dari sekolah. Jika tiangnya lemah atau rusak, maka rusaklah sekolah atau hancurnya sekolah tersebut. Akan tetapi jika kepala sekolahnya bertanggung jawab dan sungguh-sungguh menjalankan tugasnya maka sukselah sekolah tersebut. Contoh keberhasilan kepala sekolah yang sungguhsungguh dan totalitas dalam memimpin sekolah sudah banyak terbukti, begitupun sebaliknya.

Maka dapat disimpulkan kepemimpinan kepala sekolah merupakan penentu keberhasilan terwujudnya fungsi dan tujuan pendidikan nasional. Tidak bisa karena guru hebat saja, akan tetapi kepala sekolah yang memuluskan, mengeluarkan, dan menggerakkan kinerja guru menjalankan perannya dan mengeluarkan potensi potensi kebaikan dan kebertanggungjawaban guru dalam menjalankan tupoksinya. Kepala sekolah dan guru yang baik, tidak hanya bertanggung jwab dalam menajalankan tugas dan oerannya karena takut atasan saja, akan tetapi juga karena takut kepada sang maha Pencipta manusia yaitu Allah SWT.

\section{Peran Kepala Sekolah}

Menjadi kepala sekolah tidaklah mudah, dan peran kepala sekolah juga jauh berbeda dengan guru. Untuk menjadi kepala sekolahpun memiliki persyaratan tertentu yang mesti diikuti atau dipatuhi. Kepala sekolah harus memiliki dan menguasai kompetensi-kompetensi yang sudah ditetapkan. Ini semua bertujuan agar kepala sekolah mampu menjalankan perannya dalam menggerakkan, memfasilitasi, mempengaruhi, memotivasi, guru-guru agar dapat melakukan dan menciptakan pembelajaran yang kondusif sehingga terlaksana interaksi pembelajaran yang sehat dan menyenangkan sehingga semangat, motivasi serta kesungguhan anak didik dalam belajarpun ikut terpacu dan tercipta yang lama kelamaan akan melekat pada jiwa anak didik sehingga bisa melatih kebiasaan-kebiasaan pembentukan karakter yang baik pada anak didik. Peran kepala sekolah dengan maksimal dan totalitas akan membantu koleganya yaitu guru dalam menjalankan atau melaksanakan peran dan tugasnya sebagai guru.

Kepala sekolah merupakan penentu keberhasilan dalam dunia pendidikan. Kepala sekolah adalah orang yang dipercaya sebagai pemimpin untuk menyelenggrakan pendidikan dan penjamin lancarnya pelaksanaan proses belajar mengajar di sekolah. Maka dari itu kepala sekolah sudah seharusnya memiliki atau menguasai ilmu pendidikan secara menyeluruh.

Mulyasa (2006:98) memaparkan dalam mewujudkan visi dan misinya, sebagai tenaga : 1) kepala sekolah sebagai educator, 2) kepala sekolah sebagai manajer, 3) kepala sekola sebagai administrator, 4)kepala sekolah sebagai supervisor, 5) kepala sekolah sebagai leader, 6) kepala sekolah sebagai inovator, 7) kepala sekolah sebagai motivator. 
199 Peran dan Tugas Kepemimpinan Kepala Sekolah di Sekolah Dasar - Inge Kadarsih, Sufyarma Marsidin, Ahmad Sabandi, Eka Asih Febriani

DOI: https://doi.org/10.31004/edukatif.v2i2.138

\section{Permendikbud No. 16 Tahun 2018}

Dalam aturan Permdikbud No. 16 Tahun 2018 ini telah dituangkan bahwa beban kerja kepala sekolah sepenuhnya untuk melaksanakan tugas pokok supervisi terhadap guru dan tendik, manjerial, dan pengembangan kewirausahaan.

Semua kewajiban atau beban kerja kepala sekolah ini semuanya bertujuan untuk mengembangkan dan meningkatkan kualitas sekolah yang berorientasikan kepada delapan standar pendidikan nasional.

Sebagaimana yang terdapat pada Permendikbud No.16 Tahun 2018 tentang guru sebagai kepala sekolah yang dapat diberikan tugas dalam mengelola dan mengembangkan sekolah demi terwujudnya kualitas pendidikan yang bermutu di Indonesia ini.

\section{Tugas Utama Kepala Sekolah sebagai Manajerial}

Dapat kita masuk kepada arti dari manajemen, yang sebenarnya bisa kita artikan menurut pandangan kita masing masing. Namun sebenarnya manajemen itu memiliki arti kelola yang berasal dari kata manage. Segala kemaksimalan proses usaha yang dilakukan dalam menggerakkan produktivitas semua sumber daya bekerja demi mencapai tujuan dan hasil yang diharapkan.

Segala usaha dan daya yang digunakan seseorang pemimpin atau leadership disetiap satuan sekolah untuk memfungsikan kondusifitas lingkungan belajar yang harmonis, nyaman efisien dan efeketif dengan cara mengembangkan sumber daya warga sekolah.
Tugas manajerial ini berkaitan dengan pengelolaan sekolah. Rincian tugas kepala sekolah sebagai manjerial ini dapat kita lihat:

1) merancang segala bentuk perencanaan sekolah. dalam hal kegiatan ini banyak sekali yang bisa dilakukan kepala sekolah salah satunya merancang visi dan misi sekolah bersama warga sekolah

2) program pembelajaran diatur dan dikelola dengan tepat dan baik jangka panjang maupun pendek.

3) program kesiswaan

4) prasarana dan sarana diatur atau dikelola dengan tepat dan baik serta benar

5) semua kolega guru dan warga sekolah dibina dan diatur sesuai aturan oleh kepala sekolah

6) pengelolaan keuangan

7) menumbuhkan dan mengembangkan hubungan yang harmonis dengan warga masyarakat sekolah

8) membuat rancangan program kepala sekolah serta melakukan evaluasi

9) menjadi pemimpin yang bijaksana di sekolah

10) sistem informasi sekolah diatur dan ditata

\section{Tugas Utama Kepala Sekolah Sebagai Supervisor}

Sebagai kepala sekolah yang menjalankan perannya sebagai supervisi. Supervisi ini mempunyai makna yakni melakukan pengawasan terhadap sekolah bertujuan membantu guru dan tenaga kependidikan lainnya meningkatkan mutu dan efektivitas penyelenggaraan pendidikan dan pembelajaran. Pengertian supervisi seperti yang dikemukakan Ametembun (1993) dalam 
200 Peran dan Tugas Kepemimpinan Kepala Sekolah di Sekolah Dasar - Inge Kadarsih, Sufyarma Marsidin, Ahmad Sabandi, Eka Asih Febriani

DOI: https://doi.org/10.31004/edukatif.v2i2.138

Direktorat Tenaga Kependidikan Departemen Pendidikan Nasional (2008) bahwa seorang supervisor mempunyai kedudukan atau posisi lebih dari orang yang disupervisi, tugasnya adalah melihat, menilik atau mengawasi orang-orang yang disupervisi.

Supervisor (kepala sekolah) harus mampu menunjukkan perilaku seorang profesional. Pelaksanaan supervisi tenaga kependidikan harus berdasarkan kaidah-kaidah ilmiah untuk meningkatkan mutu pendidikan. Karena itu, diperlukan kelebihan dapat melihat dengan tajam permasalahan peningkatan mutu pendidikan, menggunakan kepekaan untuk memahami setiap permasalahan dan mampu memberikan alternatif untuk menyelesaikannya.

Dalam melaksanakan tugas supervisi ini tercakup beberapa kegiatan kepala sekolah diantaranya yaitu:

1) merancang program supervisi

2) melaksanakan program supervisi

3) menilai atau menikdak lanjuti program supervisi

\section{Tugas Utama Kepala Sekolah Sebagai Pemimpin Kewirausahaan}

Dalam mengemban tugas sebagai pemimpin kewirausahaan ini, tentu memiliki tujuan dalam diberikannya tugas tersebut yaitu dapat mendukung jalannya sekolah khususnya dari segi finansial. Diharapkan semua warga sekolah mempunyai sikap atau prilaku wirausaha terkhusus anak didik.

Jiwa wirausaha harus dipupuk di sekolah dan juga harus dilatih. Kepala sekolah wajib memiliki kompetensi wirausaha seperti tercakup di dalam Peraturan Menteri Pendidikan Nasional Nomor 13 Tahun 2007 tentang Standar Kepala Sekolah/Madrasah. Dimensi kompetensi kewirausahaan yaitu menciptakan inovasi, bekerja keras, memiliki motivasi yang kuat, dan pantang menyerah dan selalu mencari solusi, serta memiliki naluri kewirausahaan dalam mengelola kegiatan produksi/ jasa sekolah/ madrasah.

Kewirausahaan dalam dimensi kompetensi kewirausahaan memiliki makna nilai-nilai jiwa kewirausahaan serta semangat saling berintegrasi dan bersinergi. Kewirausahaan yang berintegritas menekankan pada karakteristiknya atau sifatsifatnya, yakni kepala sekolah yang bersifat jujur, inovatif, pekerja keras, memiliki motivasi yang kuat, pantang menyerah, selalu mencari solusi terbaik, serta memiliki naluri kewirausahaan. Karakteristik itu untuk usaha mengembangkan sekolah, keberhasilan sekolah, melaksanakan tugas pokok dan fungsi sebagai pemimpin, menghadapi kendala yang terjadi di sekolah, dan mengelola kegiatan produksi/jasa sekolah sebagai sumber belajar,tentunya memberikan manfaat besar.

Dalam pengembangan kompetensi kewirausahaan ini, ada nilai-nilai karakter yang diprioritaskan yaitu nilai spiritualitas/religiusitas, kemandirian, kerja keras, confidence, pantang menyerah, inovatif, dan kreatif serta integritas, kejujuran dan teguh pendirian

Kepala sekolah, diharapkan mampu memupuk sikap kewirausahaan pada guru yang bermuara pada kompetensi peserta didik dari sisi penanaman karakter dengan mengitegrasikan prinsip-prinsip kewirausahaan tersebut. 
201 Peran dan Tugas Kepemimpinan Kepala Sekolah di Sekolah Dasar - Inge Kadarsih, Sufyarma Marsidin, Ahmad Sabandi, Eka Asih Febriani

DOI: https://doi.org/10.31004/edukatif.v2i2.138

\section{SIMPULAN}

Membangun sebuah sekolah yang telah paten melekat nilai karakter dan cerdas pada peserta didiknya adalah bukan usaha yang mudah. Karena pekerjaan ini berhubungan dengan makhluk Allah yang bergerak dan bernyawa, yang membutuhkan ilmu, teknik, dan lebih dari itu memiliki kompetensi pada guru dan kepala sekolah yang akan berhadapan langsung dengan peserta didik. Oleh sebab itu semua komponen yang ada di sekolah harus bergerak dan bekerja sama untuk membangun generasi yang rabbani dan cerdas yang sesuai dengan tujuan pendidikan nasional.

Kepala sekolah harus terlebih dahulu paham akan tugas utamanya sebagai kepala sekolah, karena kepala sekolah merupakan key person yang sangat menentukan keberhasilan dalam memimpin dan mengelola suatu pendidikan di sekolah. Tanpa kepemimpinan yang professional dari kepala sekolah maka mustahil akan terwujud visi dan misi sekolah yang telah menjadi prioritas tujuan pendidikan di sekolah.

\section{DAFTAR PUSTAKA}

Andriani, D. (2008). Peran Kepala Sekolah Dalam Upaya Mewujudkan Perubahan Sekolah. Jurnal Manajemen Pendidikan UNY, (02), 114328.

Danim, Sudarman. 2002. Inovasi Pendidikan dalam Upaya Peningkatan Profesionalisme Tenaga Kependidikan Bandung: Pustaka Setia. Hal 145

Ekosiswoyo,

$\mathrm{R}$. (2016). Kepemimpinankepalasekolahyangefektifkunci pencapaian kualitas pendidikan. Jurnal Ilmu Pendidikan, 14(2).

Harahap, N. 2014. Penelitian Kepustakaan. Jurnal Iqra". Vol 8.No.1

Jelantik, A. K. (2015). Menjadi kepala sekolah yang profesional: Panduan menuju PKKS. Deepublish.

Lazwardi, D. (2016). Peran Kepala Sekolah Dalam Meningkatkan Profesionalisme Guru. AlIdarah: Jurnal Kependidikan Islam, 6(2).

Nasution, W. N. (2016) Kepemimpinan pendidikandisekolah. Jurnal Tarbiyah, 22(1).

Supriyana dan Sutedjo. 2019. Supervisi dan Penilaian Kinerja Tendik Jakarta: (MPPKSPKT) Dikjen GTK Kemendikbud

Suwithi ni Mayan. 2019. Pengembangan Kewirausahaan. Jakarta: (MPPKS- PKT) Dikjen GTK Kemendikbud

Wahyosumidjo. (2010). Kepemimpinan Kepala Sekolah Tinjauan Teoritik dan Permasalahannya. Jakarta: PT Raja Grafindo Persada.

Zahro, A. M., Sobri, A. Y., \& Nurabadi, A. (2018). Kepemimpinan Perubahan Kepala Sekolah Dalam Peningkatan Mutu Pendidikan. Jurnal Administrasi Dan Manajemen Pendidikan, 1(3), 358-363. https://doi.org/10.17977/um027v1i32018p358 